\title{
Artikel
}

\section{Your children are (not) your children}

\author{
Het recht op respect op gezinsleven als beperking van het recht op gezinshereniging
}

\author{
Mr. J. Werner*
}

Omdat niet zou zijn gebleken van hechte en persoonlijke banden tussen de vaders en hun kinderen, oordeelde de Afdeling Bestuursrechtspraak van de Raad van State (ABRvS/Afdeling) in 2018 in een aantal zaken dat de Staatssecretaris van Justitie en Veiligheid (de Staatssecretaris) terecht had beslist dat de gezinsband onvoldoende was aangetoond en daarom hun aanvragen om gezinshereniging met hun kind terecht waren afgewezen. ${ }^{1}$ De vaders - allen referent bij een gezinsherenigingsaanvraag - voldoen wel aan de materiële voorwaarden voor gezinshereniging uit de Gezinsherenigingsrichtlijn ${ }^{2}$ (Gri). Jorg Werner geeft een kritische analyse van de uitspraken en concludeert dat ze op gespannen voet staan met de Gezinsherenigingsrichtlijn, met jurisprudentie van het Europees Hof voor de Rechten van de Mens (EHRM) over juridisch ouderschap en met kinderrechten over contact en gezinsleven tussen ouders en kinderen.

* Mr. J. Werner is advocaat bij Hagg \& Van Koesveld Advocaten en docent bij OSR Juridische Opleidingen. De titel van dit artikel is ontleend aan de bekende tekst van Kahlil Gibran. De context en betekenis van de titelwoorden zijn in dit artikel echter een geheel andere dan in The Prophet. Het onderhavige artikel betreft een bewerking van een eerder door mij gepubliceerd artikel: J. Werner, 'Grondrechten: beperking of versterking van het recht op gezinshereniging, Asiel \& Migrantenrecht (A\&MR) 2018-9, p. 424-430.

1. ABRvS 18 juli 2018, ECLI:NL:RVS:2018:2366, JV 2020/1 m.nt. A.J.M Cleuters, ABRvS 18 juli 2018, ECLI:NL:RVS:2018:2467, ABRvS 18 juli 2018, ECLI:NL:RVS:2018:2469, ABRvS 18 juli 2018, ECLI:NL:RVS: 2018:2466 (volledigheidshalve meld ik dat in twee van de vier zaken van 18 juli 2018 een oud-kantoorgenoot van ondergetekende als advocaat optrad, zelf heb ik daarbij echter geen rol gehad), ABRvS 1 oktober 2018, ECLI:NL:RVS:2018:3174, JV 2018/185 m.nt. M.A.K. Klaassen en ABRvS 10 september 2018, ECLI:NL:RVS:2018:2940.

2. Richtlijn $2003 / 86 /$ EG.

\section{De uitspraken ${ }^{3}$}

Alle hier besproken uitspraken gaan om verzoeken van in Nederland woonachtige vaders om hun kinderen naar Nederland over te laten komen, om hier hun gezinsleven uit te gaan oefenen. De Staatssecretaris heeft de aanvragen afgewezen, omdat er geen sprake zou zijn van familie- en gezinsleven in de zin van artikel 8 van het Europees Verdrag tot bescherming van de Rechten van de Mens en de fundamentele vrijheden (EVRM). De motivering van dit standpunt verschilt enigszins van zaak tot zaak, maar in vrijwel alle zaken gebruikt de Staatssecretaris ongeveer de volgende argumenten voor dit standpunt: de vaders hadden ten tijde van de geboorte van de kinderen geen huwelijkse of daarmee vergelijkbare relatie met de moeders of konden dit niet met objectieve bewijsmiddelen aantonen, de vaders woonden nooit (eerder) met hun kinderen samen of konden dit niet met objectieve bewijsmiddelen antonen, de door de vaders gestelde regelmatige betrokkenheid bij hun kinderen (feitelijk en/of financieel) wordt van te beperkte betekenis geacht of als niet met objectieve bewijsmiddelen aangetoond. De situatie van de kinderen verschilt: sommigen verblijven bij hun moeder, sommigen elders, van één zaak is bekend dat de moeder is overleden. Voor zover de moeders betrokken zijn bij de kinderen, hebben zij toestemming verleend voor de verhuizing van hun kinderen naar hun vader in Nederland. De uitspraken van de Afdeling handelen over de hoger beroepen van de Staatssecretaris van Justitie en Veiligheid tegen uitspraken van de rechtbank Den Haag. In

3. Hoewel het dus om meerdere uitspraken gaat, ligt de nadruk van de bespreking ervan in dit artikel op de eerste en meest uitgebreid gemotiveerde ervan: ABRvS 18 juli 2018, ECLI:NL:RVS:2018:2366, JV 2020/1 m.nt. A.J.M. Cleuters, tenzij anders aangegeven 
die uitspraken is steeds gewezen op een uitspraak van de Amsterdamse meervoudige kamer (mk) van deze rechtbank, waarin kort samengevat is geoordeeld dat een beleidsregel uit paragraaf B7/3.8.1 van de Vreemdelingencirculaire $2000(\mathrm{Vc})$ strijdig is met artikel 4 lid 1 juncto artikel 16 lid 1 van de Gezinsherenigingsrichtlijn. ${ }^{4}$ Die beleidsregel geeft een uitwerking aan het bepaalde in artikel 3.14 aanhef en onder $\mathrm{c}$ van het Vreemdelingenbesluit $2000(\mathrm{Vb})$ en bepaalt dat tussen een ouder en een niet staande een huwelijk of daarmee gelijkwaardige relatie geboren kind slechts gezinsleven in de zin van artikel 8 van het EVRM bestaat, indien aan de relatie voldoende invulling wordt gegeven. ${ }^{5}$ Tegen dit oordeel komt de staatssecretaris op in alle zaken. Hoewel de staatssecretaris nooit hoger beroep heeft ingesteld tegen de genoemde mk-uitspraak en in die zaak na de het gegrond verklaarde beroep tot inwilliging van de oorspronkelijke aanvraag is overgegaan, gaat de Afdeling in de uitspraken uitgebreid in op het oordeel van de Vreemdelingenkamer Amsterdam, om daar vervolgens van af te wijken.

Inhoudelijk start de Afdeling met het uiteenzetten van de methode waarop lidstaten volgens jurisprudentie van het $\mathrm{HvJ}$ EU bepalingen van het Unierecht moet uitleggen. Als de taalversies geen verschil laten zien, zoals in dit geval, moet de tekst volgens de Afdeling worden uitgelegd aan de hand van de algemene opzet en de doelstelling van de regeling waarvan zij een onderdeel vormt. Daarbij moet rekening worden gehouden met de Unierechtelijke terminologie, waarbij rekening moet worden gehouden met de bewoordingen van de bepalingen alsook met de context, met de doelstelling van de regeling waarin die bepaling staat en ook met de ontstaansgeschiedenis van die regeling. Tot slot wijst de Afdeling erop dat de considerans kan dienen om de inhoud van de Gri te preciseren. ${ }^{6}$

De staatssecretaris heeft zich in de procedures op het standpunt gesteld dat zijn in genoemde beleidsregels neergelegde visie op gezinsleven tussen vaders en buiten huwelijk of daaraan gelijkwaardige relatie geboren kinderen in de Gri een grondslag vindt in artikel 16 lid 1 aanhef en onder b van de Gri. In deze bepaling staat dat het verzoek om gezinshereniging door de lidstaten mag worden geweigerd of kan worden ingetrokken wanneer de referent 'geen werkelijk huwelijks- of gezinsleven' (meer) onderhoudt met het gezinslid of de gezinsleden. Bij het in algemene zin bespreken van deze bepaling geeft de Afdeling vier belangrijke punten mee voor de toepassing van deze bepaling.

4. Rechtbank Den Haag, zp. Amsterdam, 15 november 2016 , ECLI:NL:RBDHA:2016:16613. Volledigheidshalve meld ik hier dat een kantoorgenote en ikzelf de vreemdeling in deze zaak gezamenlijk hebben bijgestaan.

5. Sinds Wijzigingsbesluit Vreemdelingencirculaire (WBV) 2019/9 (Stcrt. 2019, 34157, p. 13 en 69) is het 'voldoende invullings'-criterium vervangen door het 'hechte persoonlijke banden'-criterium om daarmee de terminologie van de $\mathrm{Vc}$ meer met de jurisprudentie van het EHRM in overeenstemming te brengen. Ik zie hierin geen inhoudelijke wijziging.

6. ABRvS 18 juli 2018, ECLI:NL:RVS:2018:2366, r.o. 4.2.
Ten eerste verwijst de Afdeling naar de toelichting van de Europese Commissie (EC) bij de Gri, ${ }^{7}$ waaruit volgt dat het vereiste van werkelijk gezinsleven dient om oneigenlijk gebruik van het recht op gezinshereniging tegen te gaan. Ten tweede wijst de Afdeling op het doel van dit recht zoals genoemd door de EC in dezelfde toelichting, namelijk het handhaven of herstellen van het kerngezin. Ten derde is van belang dat de Afdeling uit het arrest-Chakroun ${ }^{8}$ afleidt dat het begrip werkelijk gezinsleven in overeenstemming moet zijn met het grondrecht op eerbiediging van gezinsleven als bedoeld in artikel 8 van het EVRM en artikel 7 van het Handvest van de Grondrechten van de Europese Unie. Ten vierde wijst de Afdeling erop dat, omdat in de aanhef van het eerste lid van artikel 4 van de Gri - waarin de begunstigden van de Gri staan opgesomd - expliciet wordt verwezen naar artikel 16 van de Gri, de beslissingsautoriteit al bij de beoordeling van de aanvraag rekening kan houden met eventueel oneigenlijk gebruik. ${ }^{9}$

Dit laatste aspect speelt ook een hoofdrol bij de interpretatie van de relevante Gri-bepalingen in het Nederlands recht. Wat betreft de implementatie van de artikelen 4 lid 1 en artikel 16 lid 1 onder b van de Gri verwijst de Afdeling naar de transponeringstabel van het implementatiebesluit, waaruit volgt dat artikel 4 lid 1 van de Gri is geimplementeerd in artikel 3.14 aanhef en onder c van het $\mathrm{Vb}$ en artikel 16 lid 1 onder b van de Gri in de artikelen 18 en 19 van het $\mathrm{Vb} .{ }^{10}$ Vanwege de verwijzing in artikel 4 lid 1 van de Gri naar artikel 16 van de Gri concludeert de Afdeling daaruit dat artikel 16 ook in artikel 3.14 van het $\mathrm{Vb}$ is geimplementeerd. ${ }^{11}$

Wat de inhoud van de genoemde bepalingen betreft, vat de Afdeling samen dat artikel 4 lid 1 van de Gri en artikel 3.14 van het $\mathrm{Vb}$ beide drie cumulatieve criteria bevatten. De vereisten dat sprake moet zijn van juridisch en/of biologisch ouderschap en van gezag, zijn volgens de Afdeling identiek. Het criterium uit de Gri dat het kind ten laste moet komen aan de referent, is in artikel 3.14 van het $\mathrm{Vb}$ vertaald naar het criterium dat het kind feitelijk tot het gezin van de referent moet behoren. Op deze wijze is naar het oordeel van de Afdeling ook invulling gegeven aan de vereisten dat sprake moet zijn van financiële of materiële steun en van werkelijk gezinsleven uit artikel 16 van de Gri. Naar het oordeel van de Afdeling zijn artikel 4 lid 1 aanhef en onder c en artikel 16 eerste lid aanhef en onder b van de Gri hiermee correct geimplementeerd in de Nederlandse wet- en regelgeving, mits deze wijze van implementeren niet strijdig is met artikel 8 van het EVRM. ${ }^{12}$ Het criterium dat het kind feitelijk tot het gezin moet behoren, is uitgewerkt in paragraaf $\mathrm{B} 7 / 3.2 .1$ en de eerdergenoemde paragraaf $\mathrm{B} 7 / 3.8 .1$ van de $\mathrm{Vc}$ en daarmee gelijkgesteld aan de beleidsmatige uitwerking van het begrip gezins- en of familieleven uit artikel 8 van het

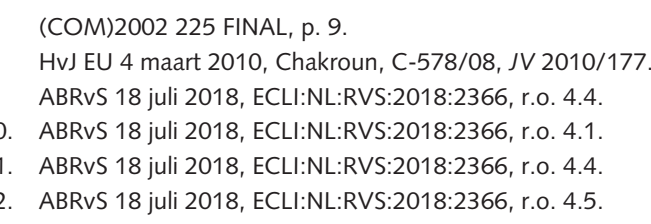


EVRM. Het aannemen van gezinsleven in de zin van deze bepaling tussen een ouder en een niet staande een huwelijk of gelijkwaardige relatie geboren kind is daarbij voor de staatssecretaris afhankelijk gemaakt van het 'voldoende invulling' geven aan de relatie. ${ }^{13}$

De Afdeling leidt vervolgens uit het L-arrest ${ }^{14}$ af dat bij een niet staande een huwelijk of daarmee gelijkwaardige relatie geboren kind de enkele biologische verwantschap tussen ouder en kind onvoldoende is om gezinsleven in de zin van artikel 8 van het EVRM aan te nemen. Of in een dergelijke situatie sprake is van gezinsleven, is volgens de Afdeling in essentie een kwestie van feitelijke aard, waarbij de eventuele samenwoning van belang is, maar ook andere aspecten relevant kunnen zijn, zoals de aard van de relatie tussen de ouder en het kind en de getoonde interesse en inzet van de ouder voor het kind. Gelet hierop komt de Afdeling tot het oordeel dat de Vreemdelingenkamer Amsterdam in de mk-uitspraak en de daarop gebaseerde bestreden uitspraken, ten onrechte heeft geoordeeld dat paragraaf $\mathrm{B} 7 / 3.8 .1$ van de $\mathrm{Vc}$ in strijd is met de Gri. ${ }^{15}$ De Afdeling voegt daaraan toe dat geen aanleiding bestaat voor het stellen van prejudiciële vragen, aangezien redelijkerwijs geen twijfel kan bestaan over de wijze waarop het Unierecht uitgelegd moet worden. ${ }^{16}$

In alle zaken komt de Afdeling tot de conclusie dat de staatssecretaris zich terecht op het oordeel heeft gesteld dat niet is gebleken van beschermenswaardig gezinsleven als bedoeld in artikel 8 van het EVRM. Ik acht het voor dit artikel niet van belang om in detail in te gaan op de precieze omstandigheden die tot deze conclusie hebben geleid. Wel valt op dat geen enkele aandacht uitgaat naar het bestaan van (eventuele) juridische gezinsbanden tussen de referent en zijn kinderen en dat de Afdeling het standpunt van de staatssecretaris accepteert dat de feitelijke uitoefening van de gezinsband onvoldoende aannemelijk is gemaakt nu het niet met objectieve bewijsmiddelen is gestaafd.

\section{Werkelijk gezinsleven en doel en systematiek van de Gri}

Mooi aan de uitspraken is dat de Afdeling voorafgaand aan de daadwerkelijke beoordeling een overtuigend en inzichtelijk toetsingskader weergeeft van de methode waarop Unierecht uitgelegd moet worden. De wijze

13. Hoewel het geen rol speelt in de hier besproken uitspraken, merk ik terzijde op dat in de Werkinstructie van de IND over de toepassing van artikel 8 van het EVRM wordt opgemerkt dat '[t] ussen de biologische vader en zijn kind dat niet is geboren uit een huwelijk of relatie [...] sprake [kan] zijn van beschermenswaardig familie- of gezinsleven als de vader beperkt invulling heeft (kunnen) gegeven aan het familieleven met zijn kind en zijn relatie wil ontwikkelen met het kind' (Werkinstructie 2019/15, p. 9). De verhouding van deze passage met de hier aangehaalde beleidsregels is mij onduidelijk, daarover is mij ook nog geen jurisprudentie bekend.

14. EHRM 1 juni 2004 , L. t. Nederland, 45582/99.

15. ABRvS 18 juli 2018, ECLI:NL:RVS:2018:2366, r.o. 4.7

16. ABRvS 18 juli 2018, ECLI:NL:RVS:2018:2366, r.o. 4.8 waarop dit kader vervolgens wordt toegepast, roept echter vragen op. De eerste stap van het door de Afdeling geschetste kader, het vergelijken van taalversies van de Gri, levert geen problemen op. Volgens de Afdeling moet daarna gekeken worden naar de systematiek en de doelstelling van de Gri, waarbij tevens relevantie toekomt aan de eigen terminologie van het Unierecht, de context van de bepaling die uitgelegd moet worden en de totstandkomingsgeschiedenis daarvan.

Bij het nemen van deze stappen is het allereerst jammer dat de Afdeling niet wat langer stilstaat bij de plaats van artikel 16 in de Gri. Artikel 16 van de Gri is opgenomen in hoofdstuk VII van de Gri, met als titel 'Sancties en beroepsmogelijkheden'. Nog vrij recent kende de Afdeling in een andersoortige procedure juist grote betekenis toe aan de plaats van artikel 16 van de Gri en concludeerde daaruit dat artikel 16 van de Gri een sanctienorm betreft. ${ }^{17}$ De nadruk op het sanctionerende karakter van artikel 16 Gri zou bijvoorbeeld relevant kunnen zijn voor de bewijslastverdeling; de bewijslast ligt bij het opleggen van een sanctie immers in beginsel bij het bestuursorgaan en niet bij de belanghebbende(n).

In onderhavige zaken lijkt de Afdeling echter in het geheel geen betekenis toe te kennen aan de plaats van artikel 16 binnen de Gri-systematiek. Wel kent de Afdeling grote en misschien zelfs wel beslissende betekenis toe aan het feit dat in de aanhef van artikel 4 lid 1 van de Gri wordt verwezen naar artikel 16 als voorwaarde. ${ }^{18}$ Hoofdstuk II van de Gri, waarin artikel 4 is opgenomen, gaat over de gezinsleden die voor toelating in aanmerking kunnen komen in het kader van de Gri. Tussen de hoofdstukken waarin artikel 4 en artikel 16 staan, worden de materiële voorwaarden voor verblijf besproken in Hoofdstuk IV over de 'vereisten voor de uitoefening van het recht op gezinshereniging', waarin in het geheel niet wordt ingegaan op het hebben van werkelijk gezinsleven als voorwaarde voor gezinshereniging. De systematiek van de Gri is op dit punt als een verkeersbord dat voor één bestemming meerdere rich-

17. Zie: ABRvS 26 april 2017, 201604740/1/V1, ECLI:NL:RVS:2017:1109, r.o. 3.6 (tweede alinea)

18. Dit gegeven gebruikt de Afdeling ook om tot de conclusie te komen dat artikel 16 van de Gri via artikel 4 van de Gri geïmplementeerd zou zijn in artikel 3.14 onder c van het Vb (ABRvS 18 juli 2018, ECLI:NL:RVS: 2018:2366, r.o. 4.4), dit in afwijking van het implementatiebesluit waarbij aan het begrip 'werkelijk huwelijks- en gezinsleven' slechts betekenis is toegekend bij besluiten tot weigering van verlenging van een verblijfsvergunning (art. $18 \mathrm{Vw}$ ) of bij de intrekking (art. $19 \mathrm{Vw}$ ) ervan (zie: Stb. 2004, 496, p. 25). De Afdeling heeft eerder op goede gronden geoordeeld dat bij het richtlijnconform uitleggen 'het gehele nationale recht in beschouwing' genomen dient te worden (zie ABRvS 25 maart 2011, 201100097/1/V3, JV 2011/193, r.o. 2.5.3.1). Maar de Afdeling wijkt hier wel erg kort door de bocht van de officiële implementatie af. Kennelijk uitgangspunt daarvan was dat artikel 16 lid 1 onder $\mathrm{b}$ van de Gri, een de Staat tot niets verplichtende kan-bepaling, slechts in het Nederlands recht kon worden toegepast nadat eerst de vreemdeling en de referent de mogelijkheid is verleend om het gezinsleven werkelijk in Nederland uit te oefenen. Het enkele feit dat artikel 4 van de Gri verwijst naar artikel 16 van de Gri is dan een wat dunne basis om de implementatie zo op te rekken. Artikel 4 van de Gri verwijst immers ook naar alle (andere) materiële voorwaarden voor gezinshereniging en toch zal niemand betogen dat het inkomensvereiste ook in artikel 3.14 van het $\mathrm{Vb}$ is geïmplementeerd. 
tingen tegelijkertijd aanwijst; het vereiste van 'werkelijk gezinsleven' uit artikel 16 van de Gri geldt zelf qua plaats binnen de systematiek van de Gri niet als voorwaarde, maar lijkt vooral een sanctienorm. In het hoofdstuk dat over de begunstigden van het recht op gezinshereniging gaat, wordt echter wel naar deze bepaling verwezen als ware het een voorwaarde voor verblijf. Een systematische analyse of een analyse waarbij de nadruk ligt op de context van artikel 16 van de Gri, kan kortom onmogelijk uitkomst bieden voor de betekenis van de bepaling en de plaats die deze heeft in de aanvraagfase.

Dit is van belang voor de wijze waarop de Afdeling de andere aspecten relevant acht voor de uitleg van de Gri, namelijk het doel en de totstandkoming van de Gri. Bij de bespreking van deze twee elementen beperkt de Afdeling zich met de verwijzing naar twee (samenhangende) standpunten van de EC: 1 ) het vereiste van daadwerkelijk gezinsleven dient ter voorkoming van misbruik van het recht op gezinshereniging; 2) het doel van het recht op gezinshereniging is het herstellen of handhaven van de eenheid van het kerngezin. Over beide punten hierna een paar opmerkingen.

De enkele vaststelling dat het begrip 'werkelijk gezinsleven' dient ter voorkoming van misbruik, lijkt op zichzelf beschouwd vooral een aanwijzing dat de EC de bepaling ziet in de context van de sanctienormen en niet in de context van de toelatingsvoorwaarden. ${ }^{19}$ Onduidelijk blijft hoe de Afdeling de interpretatie van de EC eigenlijk inpast in de eigen beoordeling, die daar haaks op lijkt te slaan. Een relevante vergelijking hierbij is de benadering door de EC van schijnrelaties. ${ }^{20}$ De EC bespreekt ook schijnrelaties in de context van het bestrijden van misbruik. De relevantie van de vergelijking met schijnrelaties ligt er allereerst in dat een schijnrelatie volgens de EC pas wordt aangenomen als het enige doel van het aangaan van de relatie ligt in het verkrijgen van een verblijfsrecht voor één van de partners en daarmee dus niet in het doel om met het verblijfsrecht samen te kunnen wonen en samen gezinsleven te kunnen uitoefenen. Wanneer deze definitie van schijnrelaties - als vorm van misbruik - analoog wordt toegepast op onderhavige casusposities, zou voor het aannemen van misbruik dus vast moeten staan dat het enig doel van het gebruik van het recht op gezinshereniging ligt in het verkrijgen van een verblijfsrecht voor het kind en daarmee dus niet primair dient om met de in Nederland verblijvende ouder gezinsleven uit te oefenen. Een voorbeeld hiervan zou dan mogelijk zijn dat een vader zijn kind naar Nederland haalt met het enige doel zijn kind aan een Nederlandse universiteit te laten

19. T. Strik, C. Ullersma \& J. Werner, 'Nareis: het 'feitelijke gezinsband'-criterium in internationaal perspectief, A\&MR 2012-9, p. 469.

20. Zie in dezen de verwijzing in de Richtsnoeren bij de Gri (COM(2014) 210 final, p. 27 en 28) naar de Richtsnoeren bij de Verblijfsrichtlijn (Richtlijn 2004/38/EG): COM(2009) 313 definitief, p. 16-17. In laatstgenoemde richtsnoeren wordt uitgegaan van een strikte definitie van misbruik door middel van schijnhuwelijken - een huwelijk met het enkele doel het in de Richtlijn neergelegde recht op vrij verkeer te kunnen genieten - en wordt de bewijslast van het bestaan van dergelijke huwelijken bij de lidstaat gelegd. studeren. Dat zou dan wellicht aangemerkt kunnen worden als een vorm van misbruik van het recht op gezinshereniging zijn, al moet gezegd worden dat er wel een groot verschil bestaat met een zuivere vorm van fraude waarbij twee mensen zonder biologische band, die elkaar niet of nauwelijks kennen, in strijd met de waarheid suggereren een relatie te hebben. Van belang bij dit alles voor de in dit artikel besproken materie is dat bij een dergelijke benadering misbruik aanzienlijk minder snel aangenomen kan worden dan in de benadering van de Afdeling.

Ten tweede is de vergelijking met schijnrelaties relevant omdat de EC daarbij een scheiding maakt tussen enerzijds de plicht voor de aanvrager om de relatie aan te tonen en anderzijds de bewijslast voor de Staat om aan te tonen dat sprake is van misbruik. Een dergelijke scheiding wordt niet gemaakt door de Afdeling en daarom is het enigszins raadselachtig waarom de Afdeling eigenlijk naar het standpunt van de EC verwijst. Zonder die motivering overtuigt deze overweging niet.

Het is bovendien een gemiste kans dat de Afdeling niet nader is ingegaan op de totstandkoming van het criterium 'werkelijk gezinsleven', want de achtergrond van dit criterium lijkt de sleutel te bevatten om de op twee gedachten hinkende systematiek van de Gri (zoals hiervoor besproken) te begrijpen. Strik beschrijft in haar proefschrift onder andere de totstandkomingsgeschiedenis van de Gri, waaruit blijkt dat Nederland in de onderhandelingen sterk heeft ingezet op het opnemen van het 'feitelijke gezinsband'-criterium als materiele voorwaarde in de Gri. ${ }^{21}$ De Nederlandse pogingen om een dergelijk criterium op te nemen als voorwaarde voor verblijf, werden tijdens de onderhandelingen echter niet begrepen, dan wel afgekeurd door de andere lidstaten. Ook de EC voelde weinig voor een extra voorwaarde. Die strategie mislukte dan ook en werd daarom bijgesteld naar de strategie ervoor te pleiten dat het ontbreken van een dergelijke gezinsband als afwijzingsgrond in de Gri moest worden opgenomen. Die strategie slaagde wel en leidde tot het vereiste van werkelijk gezinsleven uit artikel 16 van de Gri. Vlak voor een uiteindelijk politiek compromis wordt bereikt, weet Nederland bovendien een verwijzing naar dit artikel in artikel 4 van de Gri opgenomen te krijgen, waardoor ineens de suggestie wordt gewekt dat het criterium een toelatingsvoorwaarde is. ${ }^{22}$ Strik citeert in haar boek een medewerker van de EC die beschrijft op welk politiek gevoelig en enigszins chaotisch moment de verwijzing in artikel 4 naar artikel 16 tot stand is gekomen:

'De verwijzing naar de toelatingsvoorwaarden is er op het laatst tussendoor geglipt, toen er nog zoveel onenigheid over onderwerpen bestond. Ik heb daar wel op gewezen, maar het ging al naar Scifa en Core-

21. T. Strik, Besluitvorming over asiel- en migratierichtlijnen. De wisselwerking tussen nationaal en Europees niveau, Den Haag: Boom Juridische uitgevers 2011, p. 98-100.

22. T. Strik, Besluitvorming over asiel- en migratierichtlijnen. De wisselwerking tussen nationaal en Europees niveau, Den Haag: Boom Juridische uitgevers 2011, p. 98-100. 
per, en dat zijn andere onderhandelingen. Daar zitten geen experts, dus niet iedereen weet daar wat zo'n zin precies betekent en welke consequenties daaraan vastzitten. ${ }^{23}$

De hiervoor beschreven geschiedenis verklaart de dubbele signalen die de systematiek van de Gri afgeeft. De Gri leunt op twee gedachten, waarbij de grondgedachte is dat het criterium 'werkelijk gezinsleven' welbewust is geplaatst in hoofdstuk VII over sancties en beroepsmogelijkheden, omdat het bedoeld is om misbruik tegen te gaan en juist niet is bedoeld als verleningsvoorwaarde. De verwijzing naar artikel 16 in artikel 4 van de Gri laat echter een diametraal daartegenover liggende gedachte zien, waarbij het criterium juist wel wordt beschouwd als een toelatingsvoorwaarde. Deze innerlijke spanning in de Gri toont in feite een onopgelost politiek geschilpunt aan de onderhandelingstafel, een spanning die eigenlijk stof zou moeten zijn voor het stellen van prejudiciële vragen. Zeker wanneer bij de uitleg van artikel 16 van de Gri ook nader naar het doel van de Gri en naar de jurisprudentie van het HvJ EU wordt gekeken.

Het wonderlijke nu is dat de Afdeling in de uitspraken niet ingaat op het doel van de Gri, maar in plaats daarvan op het doel van het recht op gezinshereniging zoals de EC dit heeft geformuleerd. Dit heeft tot gevolg dat het lijkt alsof sprake is van een spanning tussen het doel het kerngezin te handhaven of te herstellen en het recht op gezinshereniging zelf. Zo lijkt het door de Afdeling geciteerde doel te miskennen dat ook gezinsvorming onder het recht op gezinshereniging valt (vergelijk: artikel 2 aanhef en onder d van de Gri en de uitleg daarvan door het HvJ EU in: HvJ EU 4 maart 2010, Chakroun, C-578/08, $\mathcal{F} V$ 2010/177, punt 59-61). Ook ligt in het doel van de EC erg de nadruk op het door gezinshereniging beschermen van het kerngezin als geheel, terwijl de Gri in artikel 4 lid 1 van de Gri ook expliciet een recht op gezinshereniging verschaft aan kinderen met de referent, zonder dat de andere ouder tevens mee herenigt. Verder geeft artikel 4 lid 1 van de Gri de kinderen van de echtgenoot van de referent (dus niet zijnde de kinderen van de referent zelf) een recht op gezinshereniging. Dit relativeert duidelijk de nadruk op de gedachte van de EC dat het bij de Gri altijd moet gaan om de hereniging van het kerngezin (als geheel).

Curieuzer nog is dat de Afdeling de opvatting van de EC als leidend ziet en niet het oordeel van het HvJ EU. Ten eerste vanwege het bindend gezag dat toekomt aan de oordelen van het HvJ EU, terwijl de stukken van de EC, alhoewel relevant, niet bindend zijn. Maar ook omdat het toch geen geheim genoemd kan worden dat het $\mathrm{HvJ} \mathrm{EU}$ in de jurisprudentie over de Gri bij herhaling het doel van de Gri heeft gedefinieerd als het 'bevorderen van gezinshereniging'. In recente jurisprudentie noemt het HvJ EU daarnaast ook als doel van de Gri het 'beschermen van derdelanders, met name

23. T. Strik, Besluitvorming over asiel- en migratierichtlijnen. De wisselwerking tussen nationaal en Europees niveau, Den Haag: Boom Juridische uitgevers 2011, p. 99-100. minderjarigen'. ${ }^{24}$ Deze doelen neemt het HvJ EU als uitgangspunt voor de uitleg van de Gri. Zo heeft het HvJ EU meermaals geoordeeld dat uit dit doel moet worden afgeleid dat voorwaarden die de Gri aan gezinshereniging stelt, strikt uitgelegd moeten worden en geen afbreuk mogen doen aan het nuttig effect van de $\mathrm{Gri}^{25}$

Het is merkwaardig dat de Afdeling deze vaste HvJ-EUjurisprudentie niet heeft betrokken bij de uitleg van de Gri in de hier besproken zaken. Niet alleen vanwege de miskenning van die HvJ-EU-jurisprudentie en de relevantie die de Afdeling zelf in algemene zin toe zegt te kennen aan het doel van de Gri bij de interpretatie van bepalingen van de Gri, maar ook omdat het zo'n belangrijk aspect van de uitspraken van de Afdeling is dat artikel 16 van de Gri als voorwaarde - en niet als sanctienorm - gezien moet worden. Juist uit de aangehaalde jurisprudentie van het HvJ EU volgt dat het doel van de Gri verplicht tot een strikte interpretatie van de voorwaarden die aan gezinshereniging gesteld mogen worden. De matiging van de voorwaarden aan de hand van het doel van de Gri als vast element voor het uitleggen van de Gri ontbreekt hier en dat heeft onmiskenbaar invloed op de uitkomst van de uitspraken.

Ook een ander vast element uit de HvJ EU-jurisprudentie ontbreekt in de beoordeling door de Afdeling. Al vanaf het eerste arrest over de Gri, Parlement tegen de Raad, legt het HvJ EU de nadruk op de erkenning van het idee dat de Gri een subjectief recht op gezinshereniging bevat en dat lidstaten geen beoordelingsmarge toekomt zodra voldaan is aan de voorwaarden. ${ }^{26}$ Hoewel het HvJ EU zich hierbij baseert op artikel 4 lid 1 van de Gri en de Afdeling dit artikel veel aandacht geeft, roept het oordeel van de Afdeling spanning op met het subjectief recht op gezinshereniging. Voor het kunnen aannemen van het subjectief recht op gezinshereniging lijkt het voor het HvJ EU namelijk cruciaal dat de voorwaarden en verplichtingen precies zijn omschreven. Dat de Afdeling het recht op gezinshereniging afhankelijk laat zijn van het in 'voldoende mate' invulling geven aan de ouder-kind-band (vgl. paragraaf B7/3.8.1 van de Vc), leidt ertoe dat het recht op gezinshereniging in individuele gevallen minder precies vastgesteld kan worden en een ruimere beoordelingsmarge aan de lidstaat laat. Met deze uitspraken laat de Afdeling lidstaat Nederland voorzichtig wat beoordelingsmarge afknabbelen van het subjectief recht op gezinshereniging.

Tot slot is het belangrijk om nog stil te staan bij het oordeel van de Afdeling dat het vereiste uit artikel 4 lid 1

24. Zie: HvJ EU 13 maart 2019, E., C-635/17, punt 45, en HvJ EU 16 juli 2020, B.M.M. e.a., C-133/19, C-136/19 en C-137/19, punt 25

25. Vgl. HvJ EU 4 maart 2010, Chakroun, C-578/08, JV 2010/177, punt 43; HvJ EU 6 december 2012, O, S \& L, C-356/11 en C-357/11, JV 2013/87, punt 74; HvJ EU 9 juli 2015, $K \&$ A, C-153/14, JV 2015/232, punt 50; HvJ EU 21 april 2016, Khachab, C-558/14, JV 2016/171, punt 25

26. HvJ EG 26 juni 2006, Parlement t. de Raad, C-540/03, JV 2006/313, punt 60. In latere uitspraken heeft het HvJ EU dit kenmerk van de Gri herhaald: zie bijv. HvJ EU 13 maart 2019, E., C-635/17, punt 46 en HvJ EU 16 juli 2020, B.M.M. e.a., C-133/19, C-136/19 en C-137/19, punt 26. 
aanhef en onder c van de Gri, dat het kind 'ten laste' van de referent moet komen, correct is vertaald in het vereiste uit artikel 3.14 anhef en onder $\mathrm{c}$ van het $\mathrm{Vb}$ dat het kind feitelijk tot het gezin van de referent moet behoren en al in het land van herkomst feitelijk tot het gezin van de referent moet hebben behoord. Dit begrip uit de $\mathrm{Vb}$ is enerzijds uitgewerkt aan de hand van artikel 8 van het EVRM, waarbij de Afdeling een sterke nadruk legt op de feitelijke uitoefening van het gezinsleven door ouder en kind. Anderzijds oordeelt de Afdeling dat uit het begrip 'ten laste komen' volgt dat sprake moet zijn van financiële of materiële steun van ouder. De Afdeling besteedt daarbij echter geen aandacht aan de vraag of deze uitleg van het Unierechtelijke begrip 'ten laste komen aan' overeenstemt met de jurisprudentie van het HvJ EU. De vraag is hoe dit te rijmen is met het eerder gegeven oordeel van de Afdeling dat bij het uitleggen van Unierecht betekenis toe dient te komen aan de eigen terminologie van het Unierecht. In de migratierechtelijke jurisprudentie van het $\mathrm{HvJ} \mathrm{EU}$ is veel aandacht geweest voor het begrip 'ten laste komen' en het $\mathrm{HvJ}$ EU legt de betekenis van dit begrip, afhankelijk van het specifieke instrument waarin het begrip voorkomt, met andere nuances uit. ${ }^{27}$ Over het begrip in artikel 4 van de Gri heeft het HvJ EU zich nog niet uitgelaten en het is zeer de vraag of de Afdeling dus zomaar van haar eigen interpretatie kon uitgaan, zonder daarover eerst prejudiciële vragen te stellen. In de jurisprudentie over artikel 20 van het Verdrag betreffende de Werking van de Europese Unie (VWEU) heeft het HvJ EU aangenomen dat het bij 'ten laste komen' gaat om de 'wettelijke, financiële of affectieve last' over het kind. ${ }^{28}$ Cruciaal hierbij is het woord 'of'. Het gaat volgens het HvJ EU dus niet om een cumulatief vereiste. In plaats daarvan kan zowel uit de financiële afhankelijkheid van het kind, als door een affectieve band met het kind, als uit de wettelijke verantwoordelijkheid voor het kind (bijvoorbeeld door ouderlijk gezag) worden afgeleid dat een kind ten laste komt van een ouder. Deze uitleg van het $\mathrm{HvJ}$ EU lijkt een minder restrictieve interpretatie te bevatten dan de uitleg die in de Nederlandse systematiek aan het criterium uit artikel 3.14 van de $\mathrm{Vb}$ is gegeven. $\mathrm{Nu}$, zoals eerder betoogd, uit de jurisprudentie van het $\mathrm{HvJ}$ EU volgt dat voorwaarden uit de Gri altijd strikt geïnterpreteerd moeten worden, is er veel voor te zeggen om het begrip 'ten laste komen' uit artikel 4 van de Gri in overeenstemming met deze jurisprudentielijn van het HvJ EU te interpreteren.

Daar staat echter tegenover dat dit zou veronderstellen dat ouderlijk gezag altijd impliceert dat een kind ook ten laste komt van een ouder, terwijl dit zowel in artikel 4 van de Gri als in artikel 3.14 van het Vb twee aparte cri-

27. Zie hierover uitgebreider: Migration Law Clinic VU, The requirement of 'sufficient substance' of the relationship between father and child: Conformity with Articles 4 and 16 of the Family Reunification Directive? 9-12.

28. HvJ EU 6 december 2012, O, S \& L, C-356/11 en C-357/11, JV 2013/87, punt 56, HvJ EU 10 mei 2017, Chavez-Vilchez e.a., C-133/15, punt 68 en HvJ EU 8 mei 2018, K.A. e.a., C-82/16, JV 2018/108, punt 70 teria betreft. Dat gegeven maakt het op zichzelf niet waarschijnlijk dat het ene criterium het andere automatisch veronderstelt. Toch is er meer vanuit de inhoud van het ouderlijk gezag gedacht veel voor te zeggen, zeker vanuit de opdracht in de HvJ-EU-jurisprudentie om voorwaarden aan de door de richtlijn omvatte gezinshereniging restrictief te interpreteren. Het begrip gezag is in de Gri zelf niet gedefinieerd. In de Richtsnoeren van de EC bij de Gri is aangegeven dat het gezag opgevat kan worden als een aantal rechten en plichten aangaande de zorg voor het kind, in het bijzonder het recht te bepalen waar het kind woont. De Richtsnoeren verwijzen verder voor de invulling van het begrip gezag naar het nationaal familierecht en het internationaal privaatrecht. ${ }^{29} \mathrm{Wat}$ dat laatste betreft lijkt het uitgangspunt blijkens artikel 15 van het Haags Kinderbeschermingsverdrag 1996 te zijn dat het nationaal familierecht van de verblijfsplaats van het kind geldt. ${ }^{30}$ Op het moment van het indienen van de aanvraag zal het kind weliswaar doorgaans nog niet in Nederland verblijven, maar na inwilliging wel. Zoals eerder opgemerkt omvat gezinshereniging in de Gri ook gezinsvorming. Het criterium uit artikel 3.14 onder $\mathrm{c}$ van het $\mathrm{Vb}$ dat het kind al in het land van herkomst feitelijk tot het gezin van de referent moet hebben behoord, lijkt daarmee in strijd. $\mathrm{Na}$ aankomst in Nederland geldt in beginsel het nationaal familierecht en artikel 1:247 van het Burgerlijk Wetboek (BW). Dit bepaalt dat de met het ouderlijk gezag belaste ouder de plicht heeft om het kind te verzorgen en op te voeden, waaronder mede wordt verstaan de verantwoordelijkheid voor het geestelijk en lichamelijk welzijn en de veiligheid van het kind, alsmede het bevorderen van de ontwikkeling van zijn persoonlijkheid. Naar mijn oordeel volgt uit de voornoemde plicht van de ouder met het ouderlijk gezag ten opzichte van het desbetreffende kind, dat dit kind ook ten laste komt van die ouder.

De Afdeling lijkt te makkelijk over de Unierechtelijke betekenis van het begrip 'ten laste komen' uit artikel 4 van de Gri te zijn heengestapt en te weinig onderzoek te hebben gedaan naar de materiële verhouding van dit criterium tot het in hetzelfde artikel opgenomen vereiste dat de referent het gezag over het kind dient te hebben. Uitsluitsel hierover is waarschijnlijk pas te krijgen na het stellen van prejudiciële vragen, maar er is veel voor te zeggen dat de criteria materieel grotendeels overlappen.

\section{De Gri en grondrechten}

Bij dit alles is een belangrijke vraag welke rol aan grondrechten toekomt bij de uitleg van de Gri. De Afdeling oordeelt dat uit het Chakroun-arrest volgt dat het begrip 'werkelijk gezinsleven' uit artikel 16 van de Gri uitgelegd moet worden aan de hand van artikel 8 van het

29. $(C O M(2014) 210$ final, p. 5

30. Th.M. de Boer, F. Ibili e.a., Nederlands internationaal personen- en familierecht, Deventer: Wolters Kluwer 2017, p. 178. 
EVRM. Het merkwaardige nu is dat het begrip 'werkelijk gezinsleven' niet voorkomt in dit arrest. Wat staat er wel in Chakroun? Daarin herhaalt het HvJ EU in algemene zin hetgeen is opgenomen onder het tweede punt van de considerans van de Gri, namelijk dat maatregelen aangaande gezinshereniging in overeenstemming moeten zijn met de in talrijke internationale rechtsinstrumenten neergelegde verplichting om het gezin te beschermen en het gezinsleven te respecteren. De Gri eerbiedigt naar het oordeel van het Hof namelijk de grondrechten en de beginselen die met name zijn erkend in artikel 8 van het EVRM en in het Handvest. ${ }^{31}$

Concreet gaat het voor het HvJ EU in Chakroun om de uitleg van het inkomensvereiste uit artikel 7 van de Gri. Die bepaling krijgt naar aanleiding van de aandacht voor artikel 8 van het EVRM (dan wel artikel 7 van het Handvest) niet opeens dezelfde betekenis als die bepaling(en), maar het HvJ EU verplicht een uitleg van artikel 7 van de Gri die minimaal recht doet aan de bescherming uit het grondrecht uit artikel 8 van het EVRM en artikel 7 van het Handvest. In essentie gaat het daarmee om een grondrechtconforme uitleg van artikel 7 van de Gri.

De uitleg door de Afdeling waarbij het begrip 'werkelijk gezinsleven' in feite wordt gelijkgesteld aan een zeer specifieke betekenis van artikel 8 van het EVRM, volgt in ieder geval niet dwingend uit het Chakroun-arrest. In feite voegt de Afdeling hiermee een voorwaarde toe aan de Gri die niet, althans niet expliciet, in de Gri is opgenomen en bovendien alleen wordt toegepast op bepaalde soorten van gezinshereniging. Enkel voor de referent die vader is van een kind dat hij naar Nederland wil laten overkomen en dat is verwekt op een moment dat hij geen (huwelijkse) relatie had met de moeder, geldt de voorwaarde om de feitelijke uitoefening van het gezinsleven met dit kind aan te tonen. Voor moeders geldt dit criterium helemaal niet, voor vaders die ten tijde van het verwekken van het kind een (huwelijkse) relatie hadden met de moeder, geldt dit criterium ook niet. Dit onderscheid is niet expliciet terug te vinden in de Gri en het is dus zeer de vraag of een dergelijk vergaande en specifieke interpretatie van artikel 8 van het EVRM wel in artikel 16 van de Gri gelezen mag worden. ${ }^{32}$ Dit allereerst vanwege het genoemde kenmerk aan de Gri dat deze richtlijn volgens het $\mathrm{HvJ}$ EU precieze criteria bevat en zodoende een subjectief recht op gezinshereniging bevat. Het HvJ EU ziet een grondrecht als artikel 8 van het EVRM als een minimumnorm die altijd ter bescherming van de betrokken gezinsleden gerespecteerd moet worden bij de uitleg van de Gri. De Afdeling lijkt dat uitgangspunt in de genoemde uitspraken echter te hebben aangegrepen om iets wezenlijk anders te doen; aan de hand van tamelijk specifieke EHRM-jurisprudentie worden bestaande voorwaarden uit de Gri aangescherpt voor enkel één specifieke groep rechthebbenden onder de Gri.

31. HvJ EU 4 maart 2010, Chakroun, C-578/08, JV 2010/177, punt 44

32. Zie hierover ook: M.A.K. Klaassen in zijn noot in: JV 2018/185 bij ABRvS 1 oktober 2018, 201804621/1/V1.
Naast dat dit vragen oproept over of dit wel kan in het kader van de Gri, roept dit ook vragen op in het kader van de in het Unierecht erkende grondrechten zelf. De vraag kan bijvoorbeeld worden gesteld of het gemaakte onderscheid tussen enerzijds vaders die een kind buiten een (huwelijkse) relatie hebben gekregen en anderzijds andere ouders, wel in overeenstemming is met internationaalrechtelijke discriminatieverboden. In de uitspraken is daar nu niet op ingegaan en ik zal dit daarom nu ook niet uitputtend bespreken. Vastgesteld kan in ieder geval wel worden dat het enkele feit dat het gemaakte onderscheid zelf een grondslag zou hebben in de EHRM-jurisprudentie over artikel 8 van het EVRM, op zichzelf nog geen objectieve en redelijke rechtvaardiging vormt. Het EHRM heeft immers in het verleden helder geoordeeld dat wanneer in het international recht onderscheid wordt gemaakt tussen groepen in gelijke of vergelijkbare omstandigheden, dit op zichzelf nog geen rechtvaardiging voor dat onderscheid oplevert. ${ }^{33}$ In het navolgende wordt verder nog specifiek ingegaan bij het recht op respect op gezins- en familieleven uit artikel 8 van het EVRM en artikel 7 van het Handvest en tot slot op de voor het onderwerp van dit artikel relevante kinderrechten.

Artikel 8 EVRM en artikel 7 Handvest

De uitleg die de Afdeling geeft aan artikel 8 van het EVRM is mijns inziens niet vanzelfsprekend. Die specifiek gekozen uitleg vindt zijn oorzaak allereerst in een kunstmatig scherpe scheiding tussen enerzijds het zijn van juridisch ouder (inclusief het hebben van ouderlijk gezag) en anderzijds het vereiste van het in voldoende mate invulling geven aan de band tussen ouder en kind. Het juridisch ouderschap is een juridisch feit dat wordt geregeld in nationaal familierecht en het 'voldoende invulling'-vereiste is een op artikel 8 van het EVRM gebaseerd criterium van feitelijke aard. Deze uitleg leidt ertoe dat het recht op gezinsleven uit artikel 8 van het EVRM een beperkende rol krijgt in de uitleg van het recht op gezinshereniging uit de Gri. De relevantie van het hebben van juridisch ouderschap en ouderlijk gezag - een eis die letterlijk uit de tekst van artikel 4 van de Gri volgt - wordt geminimaliseerd onder verwijzing naar EHRM-jurisprudentie over het bestaan van gezinsleven bij biologisch ouderschap. De vraag kan worden gesteld of dit niet afdoet aan het karakter van artikel 8 van het EVRM als minimumnorm. Het EHRM heeft hierover in de jurisprudentie in algemene zin benadrukt dat het EVRM de bescherming op nationaal niveau bekrachtigt in plaats van beperkt. ${ }^{34}$ Kan artikel 8 van het EVRM dan wel afdoen aan gezinsleven dat in het nationaal recht - in de vorm van juridisch ouderschap en/of gezag - al is erkend?

In de literatuur wordt bovendien wel aangenomen dat ook een juridische band, zeker wanneer sprake is van ouderlijk gezag, geldt als een vorm van gezinsleven die

33. EHRM 6 november 2012, Hode en Abdi t. het VK, 22341/09, JV 2013/1 m.nt. S.K. van Walsum, r.o. 55.

34. EHRM 30 januari 1998, United Communist Party of Turkey t. Turkije, 19392/92, par. 28. 
onder de bescherming van artikel 8 van het EVRM valt. ${ }^{35}$ Hiervoor wordt steun gevonden in EHRM-jurisprudentie. Zo oordeelde het EHRM in het Nielsenarrest dat:

'It should be observed at the outset that family life in the Contracting States encompasses a broad range of parental rights and responsibilities in regard to care and custody of minor children. The care and upbringing of children normally and necessarily require that the parents or an only parent decide where the child must reside and also impose, or authorize others to impose, various restrictions on the child's liberty. (...) Family life in this sense, and especially the rights of parents to exercise parental authority over their children, having due regard to their corresponding parental responsibilities, is recognized and protected by the Convention, in particular by Article 8 (art. 8). Indeed the exercise of parental rights constitutes a fundamental element of family life.'36

Uit de geciteerde uitspraak lijkt te volgen dat juridisch ouderschap op zichzelf al gezinsleven oplevert in de zin van artikel 8 van het EVRM en bovendien dat de uitoefening van ouderschapsrechten ook beschermd worden door artikel 8 van het EVRM. In de Nederlandse jurisprudentie is dit gegeven ook terug te vinden in de jurisprudentie van de Hoge Raad (HR). Zo oordeelde de HR in 2005 dat vanwege het feit dat een vader zijn kind had erkend, gezinsleven in de zin van artikel 8 van het EVRM aangenomen moest worden. ${ }^{37}$

Deze lijn in de jurisprudentie is niet onderkend door de Afdeling, die gezinsleven tussen ouders en buiten huwelijk of daaraan gelijkwaardige relatie geboren kinderen - in navolging van de staatssecretaris - volledig afhankelijk maakt van de vraag naar het in 'voldoende mate' invulling geven aan de gezinsband. Het is dan ook opvallend dat de Afdeling in de uitspraken slechts in één zaak aandacht besteedt aan de vraag of de referent ouderlijk gezag heeft en dat dan ook nog juist in een zaak waar dat ouderlijk gezag betwist wordt door de staatssecretaris. $^{38}$

In de uitspraak van 10 september 2018 waarbij de vader de enige ouder met ouderlijk gezag was en de moeder zelfs was overleden, kent de Afdeling geen enkele betekenis toe aan het ouderlijk gezag van de vader en herhaalt daarbij wat betreft artikel 8 van het EVRM de overwegingen uit de vier uitspraken van 18 juli 2018. ${ }^{39}$ Gelet op de aangehaalde jurisprudentie is er veel voor te zeggen om bij de beoordeling of sprake is van gezinsleven grote waarde toe te kennen aan het hebben van ouderlijk gezag door de referent. Dit impliceert immers

35. Zie bijv. K.M. de Vries, 'Right to Respect for Private and Family Life', in P. van Dijk e.a. (red.), Theory and Practice of the European Convention on Human Rights, Antwerpen: Intersentia 2018, p. 715 e.v. en M.R. Bruning, T. Liefaard \& P. Vlaardingerbroek (red.), Sdu Commentaar Jeugdrecht, Den Haag: Sdu Uitgevers 2013, p. 1569

36. EHRM 28 november 1988, Nielsen t. Denemarken, 10929/84, par. 61.

37. Zie: HR 27 mei 2005, ECLI:NL:HR:2005:AS7054, r.o. 3.4

38. ABRvS 18 juli 2018, ECLI:NL:RVS:2018:2366.

39. ABRvS 10 september 2018, ECLI:NL:RVS:2018:2940. zowel juridisch ouderschap als het hebben van gezinsleven in de zin van artikel 8 van het EVRM. Van belang daarbij is dat dit ook een mogelijkheid biedt om het bestaan van gezinsleven veel preciezer vast te stellen en te objectiveren. Dat houdt het subjectief recht op gezinshereniging in zijn volheid in stand. Het is wrang te zien dat het bestaan van gezinsleven in de uitspraken van de Afdeling nu afhankelijk wordt gemaakt van een 'voldoende mate' van feitelijke invulling, maar dat het bewijs over de feitelijke invulling tegelijkertijd deels terzijde is geschoven omdat het niet uit een objectieve bron afkomstig is. De eis dat het gezinsleven feitelijk van aard moet zijn en niet (alleen) formeel van aard, maar dat het bewijs daarvan juist weer objectief moet zijn, kan bezwaarlijk worden opgevat als een strikte interpretatie van de door de Afdeling erkende voorwaarde. Bovendien lijkt het op gespannen voet te staan met de vrije bewijsleer in het algemeen bestuursrecht.

IVRK en artikel 24 Handvest Verder is het opvallend dat de Afdeling zich wat betreft de grondrechtconforme uitleg van de Gri beperkt tot de toepassing van artikel 8 van het EVRM. Weliswaar wordt die bepaling in het Chakroun-arrest aangehaald als ondergrens voor de interpretatie van de Gri, maar in een aantal zaken betrekt het HvJ EU daarnaast ook expliciet het Internationaal Verdrag inzake de Rechten van het Kind en het daarop gebaseerde artikel 24 van het Handvest. Zo volgt uit het $\mathrm{O}, \mathrm{S} \& \mathrm{~L}$-arrest dat het HvJ EU verwacht dat bepalingen van de Gri aan de hand van artikel 7 van het Handvest en artikel 24 leden 2 en 3 van het Handvest worden uitgelegd. ${ }^{40}$ Recentelijk heeft het HvJ EU bovendien nog vrij expliciet geoordeeld dat ook artikel 4 van de Gri aan de hand van artikel 24 van het Handvest uitgelegd moet worden. ${ }^{41}$ Uit de jurisprudentie van het HvJ EU over de rechten van kinderen en de Gri volgt dat het HvJ EU deze bepalingen als materieel aanvullend beschouwt ten opzichte van artikel 8 van het EVRM en artikel 7 van het Handvest. ${ }^{42} \mathrm{Nu}$ in onderhavige zaak zo duidelijk de belangen van kinderen aan de orde zijn, is het vreemd om de grondrechtconforme uitleg van de Gri te beperken tot een uitleg aan de hand van artikel 8 van het EVRM.

In de uitspraken van 10 september 2018 en 1 oktober 2018 wordt door de Afdeling wel kort ingegaan op artikel 5 lid 5 van de Gri (de verplichting terdege rekening te houden met het belang van het kind) en artikel 24 lid 3 van het Handvest. ${ }^{43}$ In navolging van de jurisprudentie van de Afdeling over artikel 3 van het IVRK $^{44}$ en artikel 24 lid 2 van het Handvest ${ }^{45}$ behelst

40. Zie HvJ EU 6 december 2012, O, S \& L, C-356/11 en C-357/11, JV 2013/87, punt 76. Zie hierover ook: Battjes in: JV 2013/262.

41. HvJ EU 16 juli 2020, B.M.M. e.a., C-133/19, C-136/19 en C-137/19, punt 36.

42. Zie hierover ook: T.P.A. Weterings, 'Volgende stap in de versterking van de positie van het kind', A\&MR 2013-1, p. 31-32.

43. ABRvS 10 september 2018, ECLI:NL:RVS:2018:2940, r.o. 4.2.

44. ABRvS 16 april 2013, 201211554/1/V4, JV 2013/229 m.nt van D. Beltman en JV 2017/26 m.nt. J. Werner.

45. Zie bijv. ABRvS 23 mei 2013, 201302213/1/V3, JV 2013/262 m.nt. H. Battjes. 
deze toets een zeer terughoudende beoordeling van de vraag of door de staatssecretaris überhaupt rekenschap is gegeven van de belangen van de kinderen. In de zaak van 10 september 2018 acht de Afdeling het al voldoende dat in de besluitvorming is betrokken dat het kind in deze zaak - dat in haar land van herkomst na de dood van haar moeder zonder ouder woont - steeds zelfstandiger is geworden en een beroepsopleiding volgt. De materiële leegheid van het begrip 'belang van het kind' in de benadering door de Afdeling is opvallend. Als in de besluitvorming maar iets over het kind is overwogen, is het al goed genoeg, zo lijkt het. Deze benadering staat in schril contrast met de benadering van de EC die in navolging van het $\mathrm{VN}-\mathrm{Kinderrechtencomité}{ }^{46}$ vindt dat het begrip 'belang van het kind' uit artikel 5 lid 5 van de Gri en artikel 24 van het Handvest materieel ingevuld moet worden aan de hand van de bepalingen uit het IVRK. ${ }^{47}$ Vooral opvallend aan de uitspraak van 10 september 2018 is dat de Afdeling slechts aandacht aan het 'belang van het kind' besteedt in het kader van een resttoets. De relevante bepalingen van de Gri - in casu artikel 4 en 16 van de Gri - worden aldus niet uitgelegd aan de hand van artikel 5 lid 5 van de Gri, artikel 24 Handvest of het IVRK. Terwijl de Afdeling deze bepalingen van de Gri in de uitspraken van 18 juli 2018 wel uitlegde an de hand van een (specifieke) uitleg van artikel 8 van het EVRM. Mijns insziens staat dit op gespannen voet met jurisprudentie van het $\mathrm{HvJ} \mathrm{EU}$ en miskent dit dat de genoemde kinderrechtelijke bepalingen zich goed lenen om de Gri nader in te vullen.

Uit artikel 24 lid 3 van het Handvest volgt het recht van het kind om regelmatig persoonlijke betrekkingen en rechtstreekse contacten met zijn beide ouders te onderhouden. In het arrest-Deticek heeft het Hof bepaald dat eerbiediging van dit recht onbetwistbaar een belang van elk kind is. Uit deze uitspraak valt voorts af te leiden dat het Hof van oordeel is dat bepalingen van Unierecht niet uitgelegd kunnen worden op een wijze die dat grondrecht zou schenden. ${ }^{48}$ In jurisprudentie over de Gri heeft het HvJ EU hieraan gerefereerd. ${ }^{49}$ Dit op zichzelf is al veelzeggend. Weliswaar is het recht en belang van het kind om contact met de ouders te onderhouden iets anders dan het hebben van een verblijfsrecht in hetzelfde land als de ouder(s), maar voor een grondrechtconforme uitleg van de Gri is dit onmiskenbaar van betekenis. Belangrijk is daarbij vooral dat dit grondrecht van het kind op direct contact met zijn ouders geen eisen stelt aan de precieze gezinsband. Om dit te begrijpen is het IVRK van belang en de daaruit volgende wijze waarop vanuit het kinderrechtenperspectief naar gezinsleven wordt gekeken.

46. General comment No. 14. The right of the child to have his or her best interests taken as a primary consideration (art. 3, para 1), CRC/C/GC/14, Geneva: Committee on the Rights of the Child.

47. Zie de beantwoording door EC-lid Avramopoulos op vragen van het Europees Parlement, E-000345/2016, 16.6.2016, ve16001226.

48. HvJ EU 23 december 2009, Deticek, C-403/09, punt 54-55.

49. HvJ EU 6 december 2012, O, S \& L, C-356/11 en C-357/11, JV 2013/87, punt 76
Allereerst is daarbij de plaats van het IVRK binnen het Unierecht van belang. Het HvJ EU heeft in het arrest Parlement tegen de Raad erkend dat het IVRK als geheel deel uitmaakt van de algemene beginselen van het Unierecht. ${ }^{50}$ Het Handvest moet naar het oordeel van het HvJ EU worden gezien als een tekst die uitdrukking geeft an de algemene beginselen van het Unierecht. ${ }^{51}$ Ook waar het Handvest bepaalde algemene beginselen onvolledig weergeeft, gelden zij nog steeds volledig als Unierechtelijk beginsel. ${ }^{52}$ Dit is van belang omdat het Handvest een enigszins willekeurige weergave bevat van rechten uit het IVRK. ${ }^{53}$ Volgens de officiële toelichting bij het Handvest is artikel 24 van het Handvest gebaseerd op het IVRK in het algemeen en met name op de artikelen $3,9,12$ en 13 van het IVRK. ${ }^{54}$ De overige artikelen van het IVRK hebben binnen het Unierecht echter onverkort gelding in de hoedanigheid van algemeen beginsel.

In het IVRK wordt zeer uitgebreid aandacht besteed aan het recht op gezinsleven. De ouder-kindrelatie komt in totaal zo'n 37 keer aan de orde in het IVRK. ${ }^{55}$ Kenmerkend aan het IVRK is dat het de rechten van kinderen - los van de positie of het gedrag van de ouders ${ }^{56}$ - zelfstandig beschermt. Heel duidelijk komt dat naar voren in artikel 7 van het IVRK, waarin het recht van het kind wordt erkend om - voor zover mogelijk - zijn ouders te kennen en door hen te worden verzorgd. Dit algemene beginsel van Unierecht laat duidelijk zien dat zelfs als er geen feitelijke uitoefening van gezinsleven noch juridisch ouderschap bestaat, er toch nog een recht van het kind op gezinsleven met de ouder bestaat. De beperking - 'voor zover mogelijk' - die artikel 7 van het IVRK geeft op het recht van het kind zijn ouders te kennen en door hen verzorgd te worden, heeft een specifieke achtergrond die niet op een migratiecasus ziet. Deze beperking is toegevoegd ter bescherming van de praktijk van geheime adoptie die in een aantal Verdragsstaten bestaat. Met het invoegen van dit zinsdeel is voorkomen dat die praktijk afgeschaft zou moeten worden. ${ }^{57}$ Artikel 7 van het IVRK bevat evenwel geen zelfstandig recht op gezinshereniging. Toch is deze bepaling zeker relevant om conform aan de in deze bepaling neergeleg-

50. HvJ EG 26 juni 2006, Parlement t. de Raad, C-540/03, JV 2006/313, punt 35 en 37. Zie: hierover ook: P. Boeles, M. den Heijer, G. Lodder \& K. Wouters, European Migration Law, Cambridge/Antwerp/Portland: Intersentia 2014, p. 45

51. HvJ EG 26 juni 2006, Parlement t. de Raad, C-540/03, JV 2006/313, punt 38.

52. Zie: HvJ EU 11 december 2014, Boudjlida, C-249/13, punt. 30-34.

53. Zie voor uitgebreidere kritiek hierover: J. Werner \& M. Goeman, Gezinnen in de knel. Een analyse van het belang van het kind in het Europese en Nederlandse gezinsmigratiebeleid, Leiden: Defence for Children 2015, p. 49

54. Toelichtingen bij het Handvest van de Grondrechten (2007/C/303/02).

55. G. Cardol, 'De betekenis van het Internationale Verdrag inzake de Rechten van het Kind voor gezinshereniging', Migrantenrecht 2007-07, p. 40 .

56. Aan specifiek de zelfstandige rechtspositie van het kind ten opzichte van en in afhankelijkheid van de ouders heb ik uitgebreid aandacht besteed in: J. Werner, 'De (uitgestelde) rechtssubjectiviteit van het vreemdelingenkind, A\&MR 2015-1.

57. S. Detrick, A Commentary on the United Nations Convention on the Rights of the Child, Den Haag: Martinus Nijhoff 1999, p. 153. 
de gedachte over het recht op gezinsleven van het kind met zijn/haar ouder(s) de relevante bepalingen van de Gri te interpreteren. Een interpretatie op basis van artikel 7 van het IVRK leidt onmiskenbaar tot een minder restrictieve uitleg dan volgt uit de uitspraken van de Afdeling.

\section{Beperken of versterken}

Uit het voorgaande volgt duidelijk dat het recht op gezinshereniging niet zozeer beperkt moet worden door het grondrecht op gezinsleven, maar aan de hand daarvan dient te worden ingevuld. Een interpretatie van het recht op gezinshereniging aan de hand van de grondrechten die het recht op gezinsleven beschermen, levert bovendien eerder een versterking op van dit recht dan de beperking die de Afdeling eruit heeft gehaald.

In de hier besproken uitspraken heeft de Afdeling bij de uitleg van de Gri sterk de nadruk gelegd op een bepaalde interpretatie van artikel 8 van het EVRM: er zou enkel een beschermingswaardige gezinsband bestaan tussen een ouder en zijn buiten huwelijk of gelijkwaardige relatie geboren kind als aan de band met het kind voldoende invulling wordt gegeven. Een dergelijk criterium volgt niet uit de Gri en staat daarmee zelfs op gespannen voet. Ten eerste laat de systematiek van de Gri onduidelijkheid bestaan over de vraag of de mate van uitoefening van gezinsleven als voorwaarde voor verblijf mag gelden en op wie daarbij de bewijslast ligt. Bovendien roept de inhoud van het gezinsbandbegrip van de Afdeling spanning op met jurisprudentie van het EHRM over juridisch ouderschap en met het recht en het belang van het kind om gezinsleven met zijn ouder(s) te kunnen onderhouden. Ten onrechte heeft de Afdeling het recht op gezinshereniging niet aan de hand van grondrechten versterkt, maar aan de hand daarvan juist beperkt. 